\title{
A review on the important phytochemicals and their role in psoriasis
}

\author{
Ashish Pandey \\ Department of Pharmaceutical Sciences, Faculty of Medical Science \& Health, Gurukula \\ Kangri (Deemed to be University), Haridwar, 249404 (Uttarakhand), India \\ Alok Kumar Shukla* \\ Amity Institute of Pharmacy, Lucknow, Amity University Uttar Pradesh, Sector 125, Noida - \\ 201313 (U.P.), India

\section{Ramesh Chandra Dubey} \\ Department of Botany \& Microbiology, Faculty of Life Science, Gurukula Kangri (Deemed to \\ be University), Haridwar, 249404 (Uttarakhand), India \\ Ravi Pratap \\ Department of Pharmaceutical Sciences, Faculty of Medical Science \& Health, Gurukula \\ Kangri (Deemed to be University), Haridwar, 249404 (Uttarakhand), India \\ ${ }^{*}$ Corresponding author. Email: akshukla1@lko.amity.edu
}

\section{How to Cite}

Pandey, A. et al. (2021). A review on the important phytochemicals and their role in psoriasis. Journal of Applied and Natural Science, 13(3), 880 - 896. https://doi.org/10.31018/jans.v13i3.2717

\section{Article Info}

https://doi.org/10.31018/

jans.v13i3.2717

Received: May 12, 2021

Revised: July 30, 2021

Accepted: August 5, 2021

\section{Abstract}

Psoriasis may emerge at any stage of life irrespective of age, sex or geographic location. It is identified as a chronic immunelinked inflammatory skin disease that affects all human races. Psoriasis is often more Caucasian than non-Caucasian groups of human races and in geographic areas, like higher latitudes and Western countries. Therefore, attention should be paid to both genetic and environmental causes of psoriasis. Natural products have significantly contributed and encouraged the advances in skin disease treatment like psoriasis. The maximum number of phytochemicals is now being used worldwide, including various plants, herbs, and formulations. In addition, some phytochemicals like psoralen, aloe-emodin, curcumin etc. have also been isolated in pure form and have also shown their efficacy in the management of psoriasis. The presence of such phytochemicals confirms the effectiveness of few herbal therapies. This paper reviews some of the promising phytochemicals and their potential molecular target sites and mechanism of action, which may aid in designing and producing more precise and selective antipsoriatic agents. Exploring and recognizing phytochemicals as to how they function will facilitate more site-specific delivery methods for psoriasis care.

Keywords: Psoriasis, Phytochemicals, Molecular targets, Skin disease

\section{INTRODUCTION}

Psoriasis was first described and diagnosed in the $19^{\text {th }}$ century as a strongly distinguished chronic inflammatory condition erythematous papules and plaques with silvery scales of irregular keratinocytic differentiation and proliferation, polymorphonuclear white blood cell accumulation in the skin and T-cell activation (Nussbaum et al., 2021). The disease is a frequent, chronic, immune-mediated, non-communicable, painful, dry and ugly inflammatory skin problem that may engage the whole person system (Armstrong and Read, 2020). The most frequently reported psoriasis-related symptoms are skin scaling, scratching, erythema, tiredness, swelling, burning and bleeding of people with most frequently affected locations such as fingertips and toes, scalp, hands, sole, gluteus, umbilical region, breasts linings and genitals (Lebwohl et al., 2014). Severity spans this condition from a small pit on fingers' nails to skin lesions (Papp et al., 2017).

Psoriasis is a condition that profoundly affects the physical, psychological and social life of patients who are somewhat close to diseases such as obesity, diabetes, heart disease, cancer, arthritis and depression. It may result in stigmatization, low self-esteem, and increased stress, impacting interpersonal relationships and social function. Psoriasis is under neglect and maltreatment, given its significant impact on quality of life. Therefore, management of psoriasis consists of patient counseling, avoidance of stress and strain, and distinc- 
tive varieties of treatments using synthetic and natural drugs. (Passos et al., 2019; Baker et al., 2013; Kuchekar et al., 2011). National Organization for Rare Disorders (NORD) described psoriasis as a recurring rare chronic inflammatory disease of the skin, and it became so significant that one day of the year was designated as a 'World Psoriasis Day Consortium' as it has a direct influence on the goodness of life worldwide (Petkova et al., 2014; Shenefelt, 2010). Psoriasis is one of the olden days' most maltreated disorders which now continue to hunt for a suitable remedy (Pillai et al., 2012). Psoriasis is found worldwide, affecting approximately $1-3 \%$ of the population (Schleicher, 2016).

Management of psoriasis with long-term synthetic drugs may be associated with serious adverse reactions like hepatotoxicity and renal failure, sometimes leads to fatality (Mundada et al., 2009). Herbal extracts may contain various non-essential phytochemicals as a result of natural occurrence having no claim for the disease apart from those showing antipsoriatic activity. These non-essential phytochemicals may modify the activity of the main phytochemical or exhibit some activities other than antipsoriatic. Generally, mechanisms of actions of currently available natural antipsoriatic drug products aim to reverse markers including one or more of activation of nuclear factor-kB (NF-kB) pathway, Tcell dysregulation, overexpression of vascular endothelial growth factor and vascular inflammatory markers are known to play a crucial role in inflammation and angiogenesis (Sarker et al., 2020). The present study reviews the most widely reported phytochemicals, their target molecules and modes of actions, indicating that future scientists may establish more precise dosage types of suitable phytochemicals to better manage psoriasis.

\section{TYPES OF PHYTOCHEMICALS AND THEIR ROLE IN PSORIASIS}

\section{Aloe-emodin}

Aloe-emodin, 1,8-Dihydroxy-3-(hydroxymethyl)-9,10anthraquinone is a natural derivative of anthraquinone derived from the Aloe vera plant latex (Chiang et al., 2012). Its anti-inflammatory, anti-viral, anti-proliferative, analgesic and wound healing properties are particularly thought to be effective in psoriasis treatment (Dai et al., 2012). Aloe-emodine is among the principal components of the marketed liquid formula ProZ92, a natural psoriasis remedy (Maan et al., 2018). Although several possible biological molecular targets and receptors were identified and studied for anthrones, their mechanisms are not entirely explored. The antipsoriatic action of anthrones is likely because of inhibition of cellular use of oxygen, decreased intracellular spaces, decreased ribosome and mitochondria, association with DNA, inhibition of specific enzymes associated with cell proliferation, inflammation, interference with redox reactions resulting in mitochondrial damage, degradation of psoriatic epidermis membrane lipids, etc. (Deitersen et al., 2019).

\section{Amentoflavone}

Amentoflavone, a popular bioflavonoid is 8-[5-(5,7dihydroxy-4-oxo-4H-chromen-2-yl)-2-hydroxyphenyl]5,7-dihydroxy-2-(4-hydroxyphenyl)-4-chromen-4-one and naturally occurs in plants. Amentoflavone is a dimer of apigenin connected together by covalent bond at C3'-C8". Okigawa and his colleagues were the first to isolate this phytochemical in 1971 by the three plants i.e. Selaginella tamariscina, Selaginella pachystachys and Selaginella nipponica belonging to the genus Selaginella (Yu et al., 2017). Biflavonoid, amentoflavone has interesting properties such as antioxidant activity, cyclooxygenase inhibition, and induction of phospholipase $A 2$, nitric oxide synthase, inhibition of neutrophil release and degranulation of arachidonic acid (Pisoschi and Pop, 2015; García-Lafuente et al., 2009). The results of amentoflavone have been tested recently in mice in imiquimod-induced psoriasis-like lesions (An et al., 2016). Amentoflavone dose dependently blocks the mRNA expression caused by IMQ, upregulated various protein levels, TNF- $\alpha$ in skin lesion and serum IL-17A, 22 and 23 (Bonesi et al., 2018).

\section{Apigenin}

Apigenin is classified as 4',5,7-trihydroxyflavone. It occurs as a dimer in nature; known as biapigenin which has neuroprotective effects and is primarily isolated from Hypericum perforatum buds and flowers (Bonesi et al., 2018). One of the most familiar sources of apigenin is chamomile, which is mainly derived from the dried flowers of Matricaria chamomilla. It is commonly consumed as a herbal tea ingredient (Salehi et al., 2019). The flavone displays substantial NF-kB inhibition and heavy down-regulation of both a pro-inflammatory molecule of adhesion, E-selectin and IL-8. In macrophages of mouse peritoneum, the role of apigenin in the development of inflammatory cytokines i.e. interleukins (IL-6, IL-8), tumour necrosis factor (TNF- $\alpha$ ) and the granulocyte macrophage colony-stimulating factor (GMCSF) in human mast cells (HMC-1) have been previously studied (Xie et al., 2012). Apigenin reduces the level of phorbol 12-myristate 13-acetate (PMA) plus A23187 inductive effect on the growth of IL-6, IL-8, TNF $-\alpha$, and GM-CSF. In addition, apigenin ameliorated cyclooxygenase (COX)-2 expression. Apigenin inhibited PMA plus A23187 induces stimulation of the nuclear factor kappa-light-chain-enhancer of activated B cells (NF-kB), destruction of inhibitor of nuclear factor kappa $B(\mathrm{IkB})$ and activity of luciferase in stimulated HMC-1 cells. In addition, the flavones inhibit IL-6, IL-8, GMCSF, COX-2 and TNF- $\alpha$ expression by reducing intra- 
Pandey, A. et al. / J. Appl. \& Nat. Sci. 13(3), 880 - 896 (2021)

cellular Ca21 level and inhibiting activation of NF-kB.

\section{Artesunate}

Artesunate is a water-soluble, semi-synthetic, artemisinin derivative derived from plant commonly known as Little Wormwood, Artemisia annua of the family Asteraceae. It is a regular cerebral malaria treatment, and all kinds of other serious malaria. Based on ART's immune-regulatory role, it is fair to believe that ART can be considered a promising medicine for immunological or papulosquamous diseases, verified in systemic lupus erythematosus and rosacea (Li et al., 2018).

\section{Asiaticoside and Madecassoside}

The inflammatory feature of psoriasis changes the epidermis and destructively affects the wound healing process based on irregular cell differentiation and excessive keratinocyte hyperproliferation (Dabholkar et al., 2021). Plant extracts such as Psoralea corylifolia of the family Fabaceae and Centella asiatica of Apiaceae inhibit the replication of keratinocytes with $\mathrm{IC}_{50}$ values of $18.4 \pm 0.6$ and $209.9 \pm 9.8 \mathrm{mg} / \mathrm{mL}$, respectively. The antipsoriasis activity of Centella asiatica is indicated due to the presence of madecassoside triterpenoid glycosides and asiaticoside compounds with $\mathrm{IC}_{50}$ values of $8.6 \pm 0.1$ and $8.4 \pm 0.6 \mu \mathrm{M}$ respectively in extracts. The $I_{50}$ values of the two phytochemicals indicated an appreciable amount of antipsoriatic activity (Parsaeimehr et al., 2017).

\section{Astilbin}

Astilbin is a flavonoid and the principle dynamic element of Smilax glabra rhizome, which has been ordinarily utilized in conventional Chinese therapeutic framework for rewarding immune system and fiery sickness conditions (Di et al., 2016). Astilbin's capacity has been archived in few examinations to instigate apoptosis by diminishing T-cell action, expanding negative administrative cytokine (IL-10) and blocking initiated Tcell bond and migration (Raphael et al., 2020). Astilbin enhanced keratinocytic multiplication, CD4, CD81 T cells rise and rise in the level of fiery cytokines interferon (IFN- $\alpha$ ), interleukins (IL-2, IL-6, IL-17A), tissue necrosis factor (TNF- $\alpha$ ). This flavonoid is equipped for repressing discharge of IL-17, separation of Janus kinase/signal transducer and Th17 cell (Jak/STAT3) translation activator, motioning in Th17 cells, up controlling articulation of SCOSE3 in psoriatic sores proposes that astilbin explicitly impacts a few systems of STAT3 motioning in IMQ-actuated model of psoriasis like aggravation. As of late, Jak/Tyk was recommended as potential focuses for rewarding psoriasis. In psoriasis, the signal from these proteins, through articulation and enactment STAT3 and expanded in psoriatic injuries, was found that expanded paces of STAT3 and jak3 proteins, both phosphorylated and nonphosphory- lated, diminished by utilizing a high portion of astilbin in rewarded mice (Lu et al., 2013).

\section{Baicalin}

Baicalin is the key dynamic constituents for the pharmacological activity of the Scutellaria baicalensis, Chinese homegrown medication. It has been used for rewarding psoriasis for quite a long time. This phytochemical details number of various pharmacological movements like antiviral, photograph defensive exercises against intense and constant photograph harm related with oxidative pressure decrease instigated by UVB (Li et al., 2020; Wang et al., 2019; Hung et al., 2018). As of late, utilizing the touch excessive touchiness model and mouse-tail psoriasis actuated by 2,4dinitrofluorobenzene, assessed its mitigating action and keratinocyte separation in vivo, exhibiting that the topical use of baicalin cream assuages incendiary response and advances keratization normally. Baicalin in the form of cream demonstrated epidermis separation at convergences of $1 \%$ and $3 \%$ (Wu et al., 2020).

\section{Berberine}

Berberine is an alkaloid of isoquinoline with a high scope of remedial impacts that include inflammatory calming. Berberine diminished the degrees of prostaglandin E2 by restraining COX-2 articulation in a portion subordinate manner (Ehteshamfar et al., 2020). The statement of interleukin-1 alpha (IL-1 $\alpha$ ), TNF- $\alpha$ and interferon-gamma (IFN- $\mathrm{y}$ ) was accounted to be diminished by oral ingestion of berberine in four weeks (Janeczek et al., 2018). It likewise seemed to have a reducing impact on the arrival of nitric oxide (NO), a viable incendiary mediator (Sun et al., 2019).

\section{Boswellic acids}

Boswellia serrata, producing Indian Frankincense gum resin extract, has been accounted to be a calming natural cure. Boswellia serrata extract (BSE) has truly been utilized for a considerable length of time in people medication to treat numerous fiery or inflammatory sicknesses of the topical and fundamental sort (Halim et al., 2020). BSE's pharmacological impacts were due to boswellic acids, mainly 11-keto-b-boswellic acid (KBA) and acetyl-11-keto-b-boswellic acid (AKBA) as specific inhibitors of 5-lipoxygenase (5-LO) (Hussain et al., 2017).

\section{Caffeine}

Caffeine, a purine alkaloid, is 1,3,7-trimethylxanthine, obtained from green tea Camellia sinensis, coffee tree Coffea arabica and cocoa tree Cola acuminata etc. This prevents the suppressive activity of adenosine by taking action as an antagonist of the nonselective adenosine receptor $\mathrm{A} 1$ and $\mathrm{A} 2$. Cyclic adenosine monophosphate accumulation in the tissues is caused 
by phosphodiesterase (PDE) enzyme and is inhibited by this alkaloid (Barcelos et al., 2014). The body cells are secured against harm from certain substance responses, including oxidation of cancer prevention agent (Visconti et al. 2020). Cell antioxidating activity of caffeine is connected to the rummaging of hydroxyl $(\mathrm{OH})$ radical (Barrea et al., 2018). The principal metabolites of caffeine are profoundly dynamic cancer prevention agents which are 1-methylxanthine and methyluric acid (Cui et al., 2020). Another mechanism proposed is the activation of the adenosine cell surface receptors (Alashqar, 2019). Such effects may explain caffeine's probable therapeutic impact on psoriasis. Caffeine's only side effect apparently was slight itching (Iriventi et al., 2020).

\section{Camptothecin and isocamptothecin}

Camptothecin and isocamptothecin are pentacyclic alkaloid, isolated first by Wall and coworker from a Chinese tree Camptotheca acuminate in the early 1960s (Kang et al., 2018). Several studies of topical Camptotheca or CPT preparations for treating psoriasis have been published since early 1970 (Wetterauer, 2018). Those earlier studies show the effectiveness of CPT as an inhibitor of topoisomerase in the treatment of psoriasis. Liu et al. (2015) recently confirmed that 10-hydroxy-camptothecin possessed efficacy in psoriasis treatment. Subsequently, Lin et al. (2008) reveal that by inducing apoptosis, both CPT and iso-CPT hinders the development of normal adult human keratinocytes in vitro. In addition, Sun et al. (2012) in their research have shown that CPT's therapeutic role in psoriasis may be correlated with its keratinocyte and antiproliferative apoptosis activity by down regulation of telomerase function.

\section{Cannabinoids}

Cannabinoids $(\triangle-9 T H C, C B N, C B D, C B G)$ are the active components and their derivatives mainly obtained from the plant Cannabis sativa having antinflammatory properties (Ligresti et al., 2016). It has an inhibitory effect on the cell lines of rapidly proliferating tumorgenic (Wilkinson and Williamson, 2007). It is generally accepted that these compounds exhibit their response through cannabinoid receptors (CB1 and CB2), coupled with G-protein and are widely distributed across the body. Both cannabis and cannabinoids are reported for anti-inflammatory activity and were shown to change immune function by changing cytokine expression in other types of autoimmune disorders having similar symptoms to that of psoriasis, e.g. rheumatoid arthritis and Crohn's disease (Pellati et al., 2018). It has been demonstrated that the pro-inflammatory Th1 type expression is converted to the antinflammatory Th2 type (Zumbrum et al., 2015).

\section{Chamazulene}

Chamazulene obtained from Matricaria chamomilla is a byproduct called matricin, which is a non-volatile oil extract. It is believed to have anti-inflammatory activity via lipoxygenase inhibition by the formation of leukotriene B4 (LTB4) (Wang et al., 2020). The purpose behind its utilization in psoriasis is the expanded advancement of LTB4 in psoriatic plaques. Consequently, restraint brings about the progress of the illness. Chamomile oil has antimicrobial movement principally against microorganisms of the skin Staphylococcus and Candida (Rout et al., 2017).

\section{Chlorgenic acid}

Chlorogenic acids (CGAs) are antioxidant belonging to a class of secondary phenolic metabolites isolated from coffee and some other species of plants such as tea, berry fruits, cocoa, green roasted bean, citrus fruits, apples, and pears (Singh and Tripathi, 2014). This has a significant effect on psoriasis, especially plaque psoriasis and pustular psoriasis. Another exploration recorded that in fat tissue Cd11b, Cd11c and Cd68, the articulation marker qualities of macrophage and the supportive of incendiary go-between qualities, for example, MCP- 1 and TNF- $\alpha$ and F4/80 of macrophages are fundamentally diminished by CGA treatment in mice (Naveed et al., 2018).

\section{Colchicine}

Colchicine has been used in gout for several years. Psoriasis is also a disease where many studies clearly suggest that phagocytic leukocytes play a significant role. Cholchicine prevents polymorphonuclear leukocyte chemotaxis, blocks leukocyte adhesivity (Robinson and Chan, 2018) and stabilizes lysosomal membranes, the latter by breaking down microtubules (Grandi and Tramantano, 2018).

\section{Curcumin}

Curcumin, dihydroferuloyl methane, comprises of two phenolic rings system, is the principle ingredient and the key active component of the turmeric that imparts potent antioxidant activities. Curcumin exhibits antiinflammatory, antitumor and antioxidative effects (Vibhooti et al., 2016). The mechanisms that underline these diverse therapeutic effects are still not fully understood. However, cell proliferation arrest is triggered by curcumin and induces apoptosis in many forms of human and animal cells. TNF- $\alpha$ induces IL-1ß, IL-6, IL8and other pro-inflammatory cytokines and itself by activating NF-kB or MAPK (p38, JNK, and ERK) (Ohara et al., 2009). These cytokines play a significant role in various inflammatory skin disorders, such as psoriasis (Maheshwari et al., 2006). Reducing $\mathrm{Fe} 3+$ to $\mathrm{Fe} 2+$ generates hydroxyl radicals through the Fenton reaction 
(Hassan, 2018). Because of its ability to inhibit keratinocyte proliferation, curcumin can be said to have the potential of an antipsoriatic medication and is successful in the mouse tail animal model of psoriasis ( Rai et al., 2018). Moreover, recent studies in autoimmune models indicate that curcumin can modulate immune responses to the T-helper, down-regulating cell pathways of Th1 and Th17 (Aggarwal and Harikumar, 2009).

\section{Delphinidin}

Delphinidin is a derivative of anthocyanidin found richly in several coloured fruits and vegetables mainly blueberry, which is having characteristics like antinflammatory and antioxidant properties. Delphinidine effects on the proliferation, differentiation and inflammation of psoriatic epidermal keratinocytes using a psoriatic skin equivalent (PSE) model of human have been investigated recently (Chamcheu et al., 2015). Delphinidine caused cornification without impacting apoptosis, articulation of protein and mRNA of separation markers like caspase-14, filaggrin, loricrin and involucrin. This furthermore diminished the fiery markers' appearance like antimicrobial peptides S100A7-psoriasin and S100A15koebnerisin caused in psoriatic skin oftenly (Chen et al., 2019).

\section{Embelin}

Embelin, 3-undecyl 2,5-dihydroxy, 1,4-benzoquinone is a quinine derivative and active constituent of the plant called 'Vidanda' in Sanskrit 'Babrang' in Hindi and 'Fake Black Pepper' in English belonging to family Myrsinaceae. It possesses antihelmintic, antifertile, antitumor, antimicrobial, analgesic, antinflammatory and antidiabetic activity (Othman et al., 2020; Kumar et al., 2011). Embelin is accounted for to check the flagging pathways of the atomic factor-kappa B (NF-kB), which causes down-guideline of different qualities partaking in tumor cell cervical, expansion, attack, angiogenesis and aggravation, in which TNF- $\alpha$ initiates NF$\mathrm{kB}$ by wrecking its inhibitory proteins, for example IkB (Kaur and Kumar, 2012). Notwithstanding, the impact embelin has on TNF- $\alpha$ and skin irritation isn't known.

\section{Fumaric acid esters}

Fumaria officinalis, popular fumitory is a plant richly contains fumaric acid. It is known to have been used as a cure for skin disorders including leprosy as early as the $17^{\text {th }}$ century (Smith, 2017). Its use at earlier period may be represented as an early example of systemic psoriasis treatment, as psoriasis was not explicitly distinguished from leprosy until the $19^{\text {th }}$ century. It has a mixture of dimethylfumarate (DMF) and monoethylfumarate (MEF) along with the calcium, magnesium and zinc salts. DMF rapidly hydrolyzes to the principal active metabolite monomethylfumarate in vivo
(Kaur and Kumar, 2012). The suggested FAE mode of action is known primarily to be due to inhibition of T-cell activity which is considered partially due to the activation of selective apoptosis in activated $\mathrm{T}$ cells. At the same time, there is also a change in the cytokine profile from a predominantly T-helper Th1-type response to a trend of Th2-type, which appears to be beneficial in psoriasis (Charlton et al., 2019).

\section{Genistein}

Genistein, a plentiful isoflavone in soybeans is an intense mitigating and cell reinforcement specialist and a particular protein tyrosine kinase inhibitor Terra et al. (2015) have recently shown that genistein prevents a nitrosative event leading to cell proliferation and tissue protection. These discoveries show the essentialness of UVB radiation caused nitrosative harm, and help clarify the component of the photoprotective impact of genistein (Yuan et al., 2019).

\section{Glycerhiznic acid}

Liquorice from Glycerrhiza glabra is the dried and unpeeled rhizome and root. This plant root contains approximately $20 \%$ of water-soluble active ingredients and among this 3-5\%is glycyrrhizic acid (Xiong et al., 2015). Glycyrrhetic acid from liquorice extracts plays a key role in inhibiting enzymes playing key role in converting prostaglandins and glucocorticoids into inactive metabolites and increasing prostaglandin levels such as PGF2 and PGE2 (Yu et al., 2020).

\section{Gossypol}

Gossypol, also known as Boehncke is a yellow colored antinflammatory compound found in plants of the family Malvaceae, such as the Gossypium species, cotton, the Thespesia populnea (Anandjiwala et al., 2007). It is shown to exhibit antiviral and antiparasitic in vitro activity at micromolar levels and anti-tumour activity, having recognized gossypol's previously recorded antiinflammatory role. The gossypol and its derivatives are attributed as novel agents for treating psoriasis (Liao et al., 2015; Keshmiri-Neghab and Goliaei, 2014; Prakash et al., 2013). These compounds were tested as inhibitors of keratinocyte hyperproliferation (one of the psoriasis hallmarks) and antioxidant activity based on the pathophysiology of the oxidative stress theory of psoriasis (Deveci et al., 2019).

\section{Hyperforin}

Hyperforin, one of the chief active ingredients of Hypericum's extract, is reported to have wound healing, anti-inflammatory, and antibacterial properties (Farahnik et al., 2017). It has been shown that Hypericum perforatum is effective in mild to moderate psoriasis cases by modulating the immune system through CD8-mediated cytotoxicity regulation and in 
vitro TNFa-induced apoptosis inhibition (Bonesi et al., 2016).

\section{Hypericin}

Hypericin is a photodynamic agent present in the plants of the genus Hypericum. It is a phenanthroperylenequinone derivative of hexahydroxydimethyl. Photoactivated hypericin has been evidenced as a possible antipsoriatic agent in some studies (Oglah et al., 2021). For example, a powerful in vitro casein kinase II inhibitor and the epidermal growth factor receptor (EGFR) associated tyrosine kinase activity was reported to be due to photoactivated hypericin (Mansouri et al., 2017). Both casein kinase II and EGFR are involved in the etiology of psoriasis (Wölfle et al., 2014).

\section{Indirubin}

Indirubin is obtained from the plant Indigo naturalis, one of the reported Chinese herbal remedies that exhibit potential antipsoriatic efficacy (Lin et al., 2018). Nonetheless, long-term systemic use was associated with gastrointestinal tract inflammation and adverse hepatic effects (Blažević et al., 2015). To prevent the adverse systemic effects but maintain the proven effectiveness of $I$. naturalis as an antipsoriatic treatment, an alternative approach of applying the medication topically to skin lesions was introduced in 2003. Primary findings found that topical $I$. naturalis ointment diagnosis has been beneficial to recalcitrant psoriasis patients (Lin et al., 2007).

\section{Isoliquiritigin}

Isoliquiritigin is a chalcone reported to have interesting effects including calming, hostile to oxidant, against diabetic, against viral, hostile to uncontrollable and against tumour activity (Peng et al., 2015). Also, isoliquiritigin showed an inhibitory impact on the creation of IL-6, IL-12 p40 and TNF- $\alpha$ actuated by LPS (Li et al., 2014). With a particular accentuation on calming movement, isoliquiritigin stifled vascular cell grip particle (VCAM-1) and mRNA articulation and collection of E-selectin. What is more, the chalcone smothers the outflow of TNF- $\alpha$-initiated platelet endothelial cell attachment particle and down guideline of cell grip atom proteins in TNF- $\alpha$-enacted cells by obstructing $\mathrm{lkB \alpha}$ corruption and atomic movement at transcriptional levels (Zhu et al., 2019). Isoliquiritigin diminished macrophage provocative reaction by repressing the NF-kB p65 and AP-1 activation (Vani and Kumar, 2020). In RAW 264.7 macrophages, isoliquiritigin appeared to have instigated $\mathrm{HO}-1$ articulation through the ERK 1/2 pathway, with restraint of LPS-incited NO, IL-1 $\beta$, and TNF- $\alpha$ production (Chen et al., 2012), demonstrating that isoliquiritigenin is fit for decreasing cytokine IL-6 articulation, showing its conceivable use in fiery issues. It has been indicated that in vivo isoliquiritigenin up- grades psoriatic injury and lessens the neurotic pattern of psoriasis by diminishing degrees of IL- 6 and IL-8, and by decreasing articulation of CD4, CD8, CD11b/c, $\mathrm{F} 4 / 80$, and VEGF in the ear and back skin. Also, isoliquiritigenin hindered the declaration of $\mathrm{NF}-\mu \mathrm{B}$ and repressed its initiation by downregulating the phosphorylated levels of $N F-\mu B$, bringing about a decrease of the pro-inflammatory cytokines IL-6 and IL-8. Indistinguishable outcomes were found in vitro. Isoliquiritigenin brought down both the protein and mRNA convergences of NF-kB, proposing isoliquiritigenin as a promising inhibitor of NF-KB and a likely operator for psoriasis (Wu et al., 2016).

\section{Koumine}

The effects of koumine on epithelial cell mitosis and epidermal cell differentiation were assessed by collecting samples of the vaginal mucous and squamous epidermis at various doses on the tails of mice treated with methotrexate or koumine. The interleukin (IL-2) levels have been identified using immunosorbent assay linked to the enzyme. The therapeutic activity of koumine against psoriasis is linked to inhibiting epidermal cell proliferation, encouraging granular cell formation and decreasing serum IL-2 levels (Ramanunny et al., 2020).

\section{Luteolin}

The recipient impacts of the flavone luteolin have, as of late, been examined on human keratinocytes (Zhou et al., 2020). The creators displayed that TNF incited VEGF and IL-6, IL-8 from human HaCaT cells and essential keratinocytes at a convergence of $50 \mathrm{ng} / \mathrm{mL}$. Pretreatment with luteoline at centralizations of $10-100$ $\mu \mathrm{M}$ hindered arrival all things considered and mRNA articulation in a fixation subordinate way. It additionally diminished the RELA qualities TNF-actuated mRNA articulation which encoded the NF-kB subunit NF-kB p65. RELA quality articulation is improved in human psoriatic skin. Furthermore, flavones diminished the phosphorylation brought about by TNF, the authoritative DNA and NF-kB's atomic movement. In a past report was indicated the luteolin's capacity to diminish TNF-actuated phosphorylation, DNA-restricting action, and atomic movement of NF-kB (Lv et al., 2020). The hindrance of IL-6 quality articulation and emission by luteolin is of incredible worry, since IL-6 is an essential for driving the development of Th17 cells and furthermore a significant reduction in $\mathrm{HaCaT}$ associated with psoriasis pathogenesis yet not in typical keratinocyte expansion (Sung et al., 2012).

\section{9. p-Anisaldehyde \& $t$-Anethol}

The plant Illicium verum of the family Illiciaceae is generally referred to as star anise. The anti-inflammatory activity of the plant has been confirmed by two experiments in which the plant extract inhibited chemokines, 
cytokines and adhesive molecules in HaCaT-induced TNF- $\alpha /$ IFN- $\alpha$-stimulated cells and atopic skin like lesions (El-Ahmadi et al., 2021). The inhibitory effects of the plant extract and its two constituents viz. panisaldehyde and trans-anethole were investigated on the expression of ICAM-1 induced by IFN and its regulatory mechanisms in the $\mathrm{HaCaT}$ cell line (Sung and Kim, 2013). In specific, I. Verum significantly inhibited the expression of IFN-kR $\alpha$ and consequent phosphorylation of Jak2, which is primarily autophosphorylated in $\mathrm{HaCaT}$ cells treated with IFN and STAT1. I. Verum decreased the protein and the ICAM-1 mRNA. Studies have shown that cytokine signalling suppressors (SOCS) proteins are essential inflammation regulators in physiology. Among SOCS proteins, SOCS1 has shown that it inhibits IFN-k signaling via the Jak/STAT pathway (Sung and Kim, 2013). I. Verum increased SOCS1 expression, which attenuated Jak2 phosphorylation, consequent inhibition of STAT1 phosphorylation and decreased inflammatory gene expression. In addition $I$. Verum inhibited the adherence of IFN- $\alpha$-induced Jurtkat $\mathrm{T}$ cells to $\mathrm{HaCaT}$ cells by inhibiting ICAM-1 expression (Sharma et al., 2019).

\section{0. p-Coumaric acid and Pinoresinol}

Picea mariana of the family Pinaceae is a plant of genus Picea, commonly used in North America for its antiinflammatory properties. Its resin is utilized to heal wounds and treat purulent wounds from burns and skin rashes (Wang et al., 2019). In addition, P. mariana improves a variety of inflammatory conditions of the skin, including psoriasis. It was examined in a recent study that the ability for inhibition of the effects on psoriatic keratinocytes (PK) induced by TNF- $\alpha$ using $P$. mariana bark extract was compared to normal human keratinocytes (NHK) (García-Pérez et al., 2014). In specific, the extract down-regulated the biochemical pathways associated with stimulation of TNF- $\alpha$, reducing NO development, nitric oxide synthase (iNOS) induction, ICAM-1 expression, IL-6 and VEGF development, IL-8 and fractalkine formation and generation of trappin-2/elafin. Previous works documented the potency of major $P$. mariana constituents in extract such as pinoresinol, $p$ coumaric acid and resveratrol, to inhibit NO development by inhibiting the expression of iNOS mRNA (García-Pérez et al., 2014).

\section{Podophyllotoxin}

Podophyllotoxin from the plant Podophyllum peltatum is a highly concentrated $(99.2 \%)$ material and is known from a couple of open clinical studies for antipsoriatic properties. Podophyllin concentration of $5-25 \%$ was primarily used in earlier studies. So far, there are total of 35 psoriasis known cases, treated openly with topical application of podophyllin daily or alternatively every second day. During the treatment period, approximately
$75 \%$ of patients showed a marked clearing. Full remission was observed in some cases during a 9 month follow-up period. Podophyllin tolerance has been reported as strong, given the substance's high concentration. However there were reported adverse reactions like irritation and pruritis. Podophyllin is a strong irritant, particularly at high concentration levels. Podophyllotoxin is an active agent present in podophyllin. If special steps are not taken, podophyllotoxin can easily be converted into inactive podophyllotoxin (Johnson et al., 2018; Choudhary et al., 2016).

\section{Polyandric acid A \& B}

Dodoneae polyandra of the family Sapindaceae is a medicinal plant in Australia and northern Kaanju. Two furanoclerodane diterpenoids were established as key active components named polyandric acid $A$ and $B$. Both compounds exhibited potent antinflammatory activity in mouse ear oedema model induced by TPA (Rios et al., 2019). Polyandric acid type $A$ has been reported to check interleukin- $1 \beta$ development in acute inflammatory model for skin and to minimize the thickness of ear and accumulation of myeloperoxidase in a chronic skin inflammatory model (Simpson et al., 2014). A substantial decrease in the secretion of IL-6 has also been observed in primary human neonatal keratinocytes. Lately, the $D$. polyandra induced Keratinocytes shoot high amounts of pro-inflammatory cytokines IL-1 $\beta$ and TNF- $\alpha$ which induce multiple inflammatory responses and intensify the symptoms.

\section{Psoralen}

Psoralens chemically 8-methoxy psoralens, most widely used psoralen derivative in photochemotherapy are compounds belong to the heterocyclic group, some of which are photosensitizing agents called furocoumarins. It is commercially isolated from the plant Ammi majus (Singhvi et al., 2020). Psoralens, when irradiated at $365 \mathrm{~nm}$, covalently integrate with pyrimidine bases in nucleic acid. Cross connections between two DNA strands also occur when psoralens act as bivalent reagents, interact with opposite double helix strands through pyrimidine bases (Buhimschi et al., 2020). This inhibitory impact is one potential explanation of the psoralens effects and long-wave UV radiation in psoriasis, characterized by increased rate of epidermal cell turnover (Stern and Richard, 2020).

\section{Quercetin}

Quercetin demonstrated fascinating therapeutic properties, including anti-inflammatory, anti-viral, antibacterial, and anti-tumor effects (Rengasamy et al., 2019). Its free radicals scavenging ability, transition metal ions binding, and prevention of lipid peroxidation make the flavonol a good antioxidant for consideration (Alalaiwe et al., 2018). It has been shown that quercetin 
reduces activation of BV-2 microglia mouse STAT-1 by IFNk. Quercetin also reduced the activation of LPS triggered NF- $k B$ and STAT-1, iNOS expression. In human keratinocytes, the capacity of quercetin to inhibit the production of cytokines IL-1 $\beta$, IL- 6, IL- 8 and TNF- $\alpha$ through induction of ultraviolet irradiation has been demonstrated (Hämäläinen et al., 2007).

\section{Resveratrol}

Resveratrol, 3,4,5-trihydroxy-trans-stilbene is a phytoalexin that inhibits the development of proatherogenic eicosanoids by platelets and neutrophils, exercising anti-inflammatory action (Kjaer et al., 2015), inhibits protein-tyrosine kinase that modulates proliferation and differentiation of cells and signaling processes in immune system cells, biological processes involving inflammatory response and serious pathologies such as cancer, arteriosclerosis and psoriasis (Oliveira et al., 2017).

\section{Sulphoquinovosyldiacylglycerol1,2-di-O-palmit oyl-3-O-(6-sulphoadquinovopyranosyl)-glycerol} Sulphoquinovosyldiacylglycerol1,2-di-O-palmitoyl-3-O(6-sulphoadquinovopyranosyl)-glycerol is found in Wild's fern in South America, with the common name calaguala Polypodium decumanum (Polypodiaceae). Medical use in the treatment of skin disorders psoriasis, atopic dermatitis and vitiligo has been reported (Gonzales et al., 2010). Its inhibitory activity was caused by polyunsaturated fatty acids (Nestor et al., 2014). Platelet-activating factor (PAF) is another phospholipid derived mediator that is involved in the pathogenesis of psoriasis. The elevated levels of PAF derived from psoriatic scales indicate its presence in the disease. It is also considered to be a potent chemoattractant and autocoid injection cause increased vascular permeability and vasodilatation, which are common signs of psoriasis inflammation (Berman et al., 2016).

\section{Syllimarin}

Silymarin, commonly known as 'milk thistle' is derived from the plant Silybum marianum of family Asteraceae and Compositae. Milk Thistle includes silybin, silydianin, and silychristin (Dorjay et al., 2018). The importance of silymarin in the care of psoriasis may be due to its potential to enhance liver endotoxin elimination, inhibition of CAMP phosphodiesterase and prevention of synthesis of leukotrienes. For patients with psoriasis, cAMP and leukotrienes have been found in abnormally high levels and the normalization of these levels may improve the condition (Sabir et al., 2014).

\section{Methylthiobutylisothiocyanate (MTBI)}

4-Methylthiobutylisothiocyanate (MTBI) is a lesserknown isothiocyanate (ICT), which is produced as a result of hydrolysis of the glucosinolate named gluco- erucin (GER or 4-methylthiobutylglucosinolate) present in Eruca sativa, popularly known as rocket seed (Esteve, 2020). Both GER and MTBI are reported to have direct antioxidant activity due to the oxidized form of MTBI, SFN (4-methysulfinylbutyl ITC), and is believed the most active enzyme of phase II inductive causer among ITCs through glutathione transferase, quinone reductase, and heme oxygenase induction (Yehuda et al., 2012). Additionally, the role of MTBI in the activation of THP-1 cells was examined by evaluating mRNA expression of known psoriasis related factors like IL-1b, IL-12/23p40, ICAM-1, and TNF-a (Yehuda et al., 2009).

A summarized list of phytochemicals, along with their common names, biological sources and their families, is given in Table 1.

Plants and plant-based therapy is an ancient approach that considers emotional, mental, and spiritual well-being. It is a naturopathic approach that includes lifestyle, emotional, mental, and spiritual concerns. Herbs have phytochemicals in the form of the active molecule which work as drug e.g. opiates (used for alleviation of pain, sedation), digitalis (helpful against heart failure and cardiac arrhythmias) and taxol (anticancer). Phytochemical compounds can be used for the management of many diseases. Phytochemicals are economical than synthetic drugs as these are naturally produced in plants. The ideal norm for any medicinal product (synthetic or natural) is its non-toxic nature, effectiveness, specificity stability and potency. Although herbal medicines have less potency than synthetically structured drugs, these are considered less toxic, having fewer side effects than synthetic drugs. People have blind trust in them as phytochemicals and their products are commonly used and considered harmless. They are appropriate as they can manage any disease without any harmful side effects. These are not only suitable in the treatment of various health-related problems but are also widely used for personal beautification and for curing skin-related issues. They do not generally have synthetic drug-like side effects. On the other hand, synthetic drugs are synthesized by a different method in the laboratory. These are not found in nature.

Synthetic drugs can be seriously harmful, even used in very low doses (Nisar et al., 2018). For example; A lot of examples reported in literature which is related to the side effects caused by synthetic drugs, e.g. Paracetamol is well known antipyretic drug but it can also cause liver poisoning as a major side effect (Rotundo and Pyrsopoulos, 2020). Naproxen causes gastrointestinal side effects (Emerson et al., 2020). Ibuprofen is another antipyretic drug that may cause nephrotoxicity, including renal failure, when given to volume-depleted children. Medical plant poisoning has been documented, usually due to wrong identification of the plants in 
Pandey, A. et al. / J. Appl. \& Nat. Sci. 13(3), 880 - 896 (2021)

Table 1. List of phytochemicals, their common names, biological sources and families.

\begin{tabular}{|c|c|c|c|c|}
\hline $\begin{array}{l}\text { S. } \\
\text { No }\end{array}$ & Phytochemical & Common name & Source & Family \\
\hline 1 & Aloe-emodin (1) & Ghritakumari & Aloe vera (L.) Burm. & Liliaceae \\
\hline 2 & Amentoflavone (2) & Spring & $\begin{array}{l}\text { Selaginella tamariscina, Selaginella } \\
\text { nipponica, and Selaginella } \\
\text { pachystachys }\end{array}$ & Selaginellaceae \\
\hline 3 & Apigenin (3) & Chamomile & Matricaria chamomilla & Asteraceae \\
\hline 4 & Artesunate (4) & Sweet Wormwood & $\begin{array}{l}\text { A derivative of artemisinin from Arte- } \\
\text { misia annua }\end{array}$ & Asteraceae \\
\hline 5 & $\begin{array}{l}\text { Asiaticoside (5), Madecassoside } \\
\text { (6) }\end{array}$ & $\begin{array}{l}\text { Gotu kola/Indian Pen- } \\
\text { nywort }\end{array}$ & Centella asiatica & Apiaceae \\
\hline 6 & Astilbin (7) & $\begin{array}{l}\text { St John's wort Fava } \\
\text { d'anta }\end{array}$ & $\begin{array}{l}\text { Hypericum perforatum, Dimorphan- } \\
\text { dra mollis }\end{array}$ & $\begin{array}{l}\text { Fabaceae } \\
\text { Hypericaceae }\end{array}$ \\
\hline 7 & Biacalin (8) & $\begin{array}{l}\text { Chinese } \\
\text { \&Baikal skullcap }\end{array}$ & $\begin{array}{l}\text { Scutellaria bai- } \\
\text { calensis and Scutellaria lateriflora }\end{array}$ & Lamiaceae \\
\hline 8 & Berberine (9) & OregonGrape & Mahonia aquifolium & Berberidaceae \\
\hline 9 & Boswellic acid (10) & Indianfrankincense & Boswellia serrata & Burseraceae \\
\hline 10 & Caffeine (11) & coffee tree, green tea & Coffea arabica Camellia sinensis & $\begin{array}{l}\text { Rubiaceae, } \\
\text { Theaceae }\end{array}$ \\
\hline 11 & $\begin{array}{l}\text { Camptothecin (12), Iso- } \\
\text { Camptothecin (13) }\end{array}$ & Heaven wood tree & Camptotheca accuminata Decaîsne & Nyssaceae \\
\hline 12 & Cannabinoids $(14,15,16,17)$ & Hemp, Asian Hemp & Cannabis sativa, Cannabis indica & $\begin{array}{l}\text { Cannabaceae, } \\
\text { Cannabaceae }\end{array}$ \\
\hline 13 & Chamazulene (18) & $\begin{array}{l}\text { chamomile wormwood } \\
\text { yarrow }\end{array}$ & $\begin{array}{l}\text { Matricaria chamomilla, Artemisia } \\
\text { absinthium }\end{array}$ & Asteraceae \\
\hline 14 & Chlorogenic acid (19) & $\begin{array}{l}\text { Fruits, vegetables, } \\
\text { coffee. }\end{array}$ & Coffea Arabica, Thea sinesis & $\begin{array}{l}\text { Rubiaceae, } \\
\text { Theaceae }\end{array}$ \\
\hline 15 & Cholchicine (20) & Autumn crocus & Colchicum autumnale & Colchicaceae \\
\hline 16 & Curcumin (21) & Turmeric & Curcuma longa & Zingiberaceae \\
\hline 17 & Delphinidine (22) & $\begin{array}{l}\text { Wild Lowbush Blueber- } \\
\text { ry }\end{array}$ & Vaccinium angustifolium & Ericacae \\
\hline 18 & Embelin (23) & False Black Pepper & Embelia ribes & Myrsinaceae \\
\hline 19 & Fumeric acid (24) & Bolete mushrooms & $\begin{array}{l}\text { Fumaria officinalis, Boletus fomen- } \\
\text { tarius }\end{array}$ & $\begin{array}{l}\text { Fumariaceae, } \\
\text { Polyporaceae }\end{array}$ \\
\hline 20 & Genistein (25) & Nilgiri Flemingia & $\begin{array}{l}\text { Flemingia vestita and F. macrophyl- } \\
\text { la, and coffee }\end{array}$ & Fabaceae \\
\hline 21 & Glycerhiznic acid (26) & Licorice, Glycyrrhiza & Glycyrrhiza glabra & Leguminasae \\
\hline 22 & Gossypol (27) & Cotton & Gossypium species & Malvaceae \\
\hline 23 & Hypericin (28) & St John's Wort & Hypericum perforatum & Hypericaceae \\
\hline 24 & Hyperforin (29) & St John's Wort & Hypericum perforatum & Hypericaceae \\
\hline 25 & Indirubin (30) & Indigo & Indigo naturalis & Acanthaceae \\
\hline 26 & Isoliquiritigenin (31) & Mongolian glycyrrhiza & $\begin{array}{l}\text { Glycyrrhiza uralensis, Glycyrrhiza } \\
\text { glabra }\end{array}$ & Leguminosae \\
\hline 27 & Koumine (32) & Heartbreak Grass & Gelsemium elegans & Loganiaceae \\
\hline 28 & Luteolin (33) & Mint & Salvia tomentosa & Lamiaceae \\
\hline 29 & P-anisaldehyde (34) & Star Anise & Illicium verum & Schisandraceae \\
\hline 30 & $\begin{array}{l}\text { P-coumaric acid (35) and P- } \\
\text { resinol (36) }\end{array}$ & Black spruce & Picea mariana & Pinaceae \\
\hline 31 & Podophyllotoxin (37) & $\begin{array}{l}\text { Mayapple Himalayan } \\
\text { Mayapple }\end{array}$ & $\begin{array}{l}\text { Podophyllum peltatum, Podophyl- } \\
\text { lum hexandrum }\end{array}$ & Berberidaceae \\
\hline 32 & Polyandric acid A (38) \& B (39) & $\begin{array}{l}\text { Polyandric acids, Do- } \\
\text { donea }\end{array}$ & Dodoneae polyandra & Sapindaceae \\
\hline 33 & Psoralen (40) & Babchi & Psoralea corylifolia & Fabaceae \\
\hline 34 & Quercitin (41) & Black oak & Quercus tinctoria & Fagaceae \\
\hline 35 & Resveratrol (42) & Black spruce & Picea mariana & Pinaceae \\
\hline 36 & $\begin{array}{l}\text { Sulphoquinovosyldiacylglycerol1,2 } \\
\text {-di-O-palmitoyl-3-O-(6- } \\
\text { sulphoadquinovopyranosyl)- } \\
\text { glycerol (43) }\end{array}$ & Willd Calaguala & Polypodiumdecumanum & Polypodiaceae \\
\hline 37 & Syllimarin (44) & Milk thistle & Silybum marianum & Asteraceae \\
\hline 38 & $\begin{array}{l}\text { 4-methylthiobutylisothiocyanate } \\
\text { (45) }\end{array}$ & Rocket seeds & Eruca sativa & Brassicaceae \\
\hline
\end{tabular}

Note: Numbers in parenthesis following the names of the phytochemicals in column $2^{\text {nd }}$ refer to their respective molecular structure in Fig 1. 


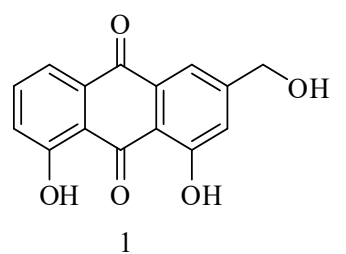<smiles>O=C1CC(c2ccc(O)c(-c3c(O)cc(O)c4c3CC(c3ccc(O)cc3)=CC4=O)c2)Oc2cc(O)cc(O)c21</smiles><smiles>O=c1cc(-c2ccc(O)cc2)oc2cc(O)cc(O)c12</smiles>

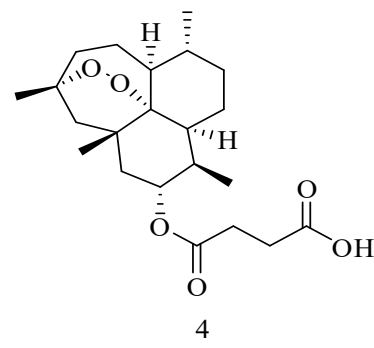

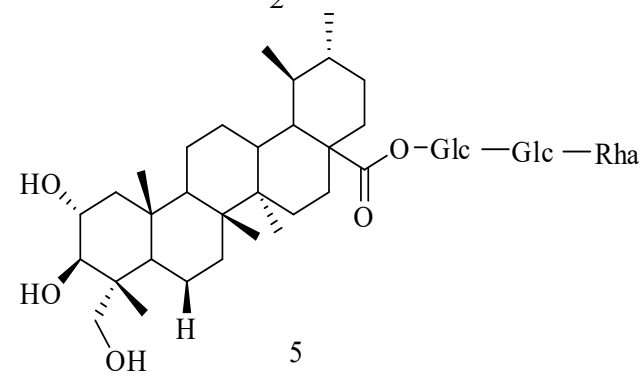

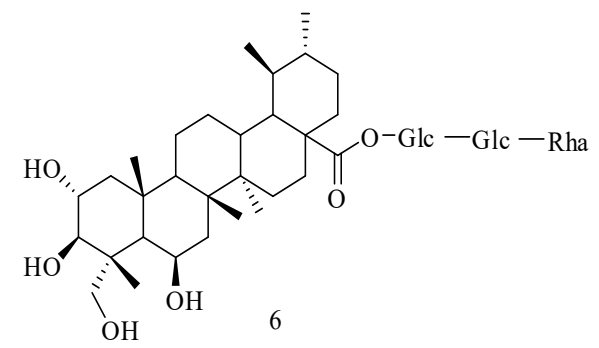<smiles>O=C1CC(c2ccccc2)Oc2cc(O[C@@H]3O[C@H](C(=O)O)[C@@H](O)[C@H](O)[C@H]3O)c(O)c(O)c21</smiles>

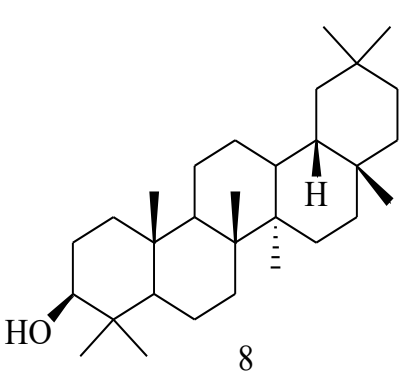<smiles>C[C@H]1CC[C@]2(C)CC[C@]3(C)C(=CC(=O)[C@@]4(C)C3CC[C@@]3(C)C4CC[C@H](C)[C@@]3(C)C(=O)O)C2[C@@H]1C</smiles>

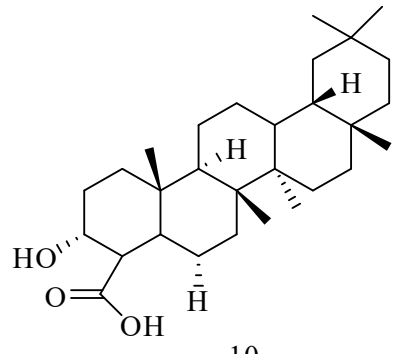<smiles>Cn1c(=O)c2c(ncn2C)n(C)c1=O</smiles><smiles>CC[C@]1(C)C(=O)OCC2C(=O)N3Cc4cc5ccccc5nc4C3CC21</smiles><smiles>CC[C@]1(C)C(=O)OCC2C(=O)N3Cc4cc5cc(O)ccc5nc4C3CC21</smiles><smiles>CCCCCc1cc(O)c2c(c1)OC(C)(C)C1CCC(C)CC21</smiles><smiles>Cc1cc(O)c2c(c1)OC(C)(C)C1CCC(CO)=CC21</smiles>

15<smiles>CCCCCc1cc(O)c2c(c1)OC(C)(C)C1CCC(C(=O)O)=CC21</smiles>

16<smiles>CCCCCc1cc(O)c(C2CC(C)CCC2C(C)=O)c(O)c1</smiles>

17<smiles>CCc1ccc(C)c2ccc(C)c-2c1</smiles>

18<smiles>O=C(/C=C/c1ccc(O)c(O)c1)O[C@@H]1C[C@](O)(C(=O)O)C[C@H](O)[C@H]1O</smiles>

19

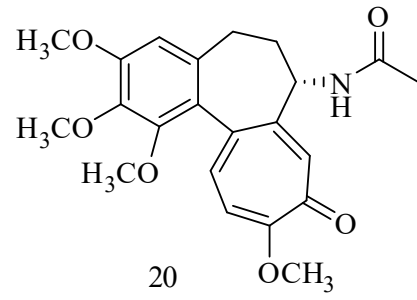

$20 \quad \mathrm{OCH}_{3}$ 
<smiles>CCCCCCCCCCCC1C(=O)C(O)CC(=O)C1O</smiles><smiles>O=C(O)/C=C/C(=O)O</smiles>

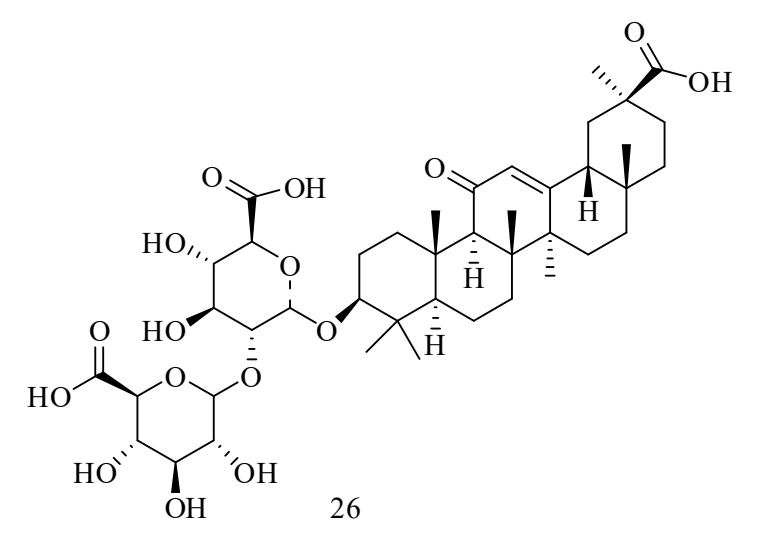<smiles>CC(C)=CCCC1(CC=C(C)C)CC2(CC=C(C)C)C(=O)C1(CC=C(C)C)CC(CC=C(C)C)CC2(CCC=C(C)C)C(=O)C(C)O</smiles>

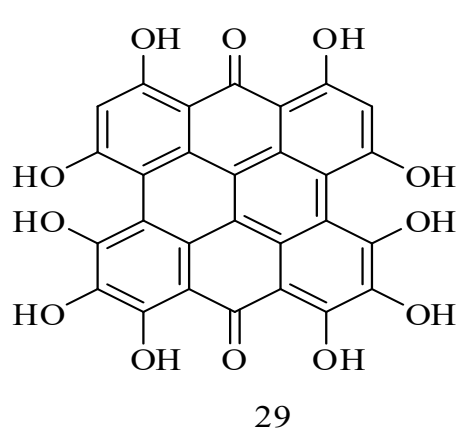<smiles>O=C1Nc2ccccc2/C1=C1/Nc2ccccc2C1=O</smiles><smiles>O=C(/C=C/c1ccc(O)cc1)c1ccc(O)cc1O</smiles>

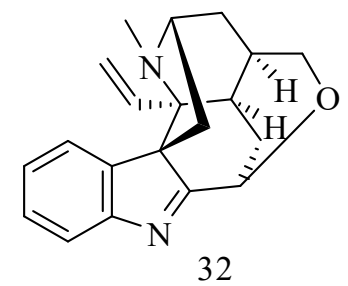<smiles>COc1ccccc1C=O</smiles>

34<smiles>O=C(O)/C=C/c1ccccc1O</smiles>

35<smiles>COc1cc(CC2CO[C@@H](c3ccc(O)c(OC)c3)[C@H]2CO)ccc1O</smiles>

36 
<smiles>COc1cc([C@H]2c3cc4c(cc3[C@@H](O)[C@@]3(O)COC(=O)[C@H]23)OCO4)cc(OC)c1OC</smiles>

37<smiles>O=C1C=Cc2cc3c(cc2C1)OCC3</smiles>

40<smiles>C[C@]12CC[C@@H](COC(=O)c3ccccc3)[C@@H](CCc3ccoc3)[C@H]1C[C@@H](O)CC2C(=O)O</smiles>

38

41<smiles>C[C@H]1CC[C@]2(C)C(C(=O)O)CC[C@H](C=O)[C@@]2(CCc2ccoc2)[C@]1(C)CCc1ccccc1</smiles>

39<smiles>Oc1ccc(/C=C/c2cc(O)cc(O)c2)cc1</smiles>

42<smiles>COc1cc(C2Oc3cc([C@@H]4Oc5cc(O)cc(O)c5C(=O)[C@H]4O)ccc3OC2CO)ccc1O</smiles>

43<smiles>CSCCCCN=C=S</smiles>

44

Fig. 1. Showing the molecular structures of-Aloe-emodin (1), Amentoflavone (2), Apigenin (3), Artesunate (4) Asiaticoside (5), Madecassoside (6), Astilbin (7), Biacalin (8), Berberine (9), Boswellic acid (10), Caffeine (11), Camptothecin (12) \& Iso-Camptothecin (13), Cannabinoids (14,15,16,17), Chamazulene (18), Chlorogenic acid (19), Cholchicine (20), Curcumin (21), Delphinidine (22), Embelin (23), Fumeric acid (24), Genistein (25), Glycerhiznic acid (26), Gossypol (27), Hypericin (28), Hyperforin (29), Indirubin (30), Isoliquiritigenin (31), Koumine (32), Luteolin (33), P-anisaldehyde (34), Pcoumaric acid (35), P-resinol (36), Podophyllotoxin (37), Polyandric acid A (38), Polyandric acid B (39), Psoralen (40), Quercitin (41), Resveratrol (42), , Syllimarin (43), 4-methylthiobutylisothiocyanate (44).

the form in which they are sold, or their improper processing and administred by untrained persons. Due to this, now many chemists have started switching their field from synthetic to natural side in order to explore nature more and more. The phytochemicals have better performance than synthetic drugs with the lesser and delayed risk of side effects; their efficacy even in chronic conditions and widespread availability at generally low-cost products (Nisar et al., 2018).

In India, phytochemicals, as well as herbal plants, have been the most abundant source of health care and life improvement since ancient. Indian medicinal systems like Ayurveda, Unani and Siddha have been the kingpin for health care in society since ancient times. Ayurveda predominantly uses phytochemicals in their preparations and formulations. Now in the modern era, about $24 \%-27 \%$ of drugs are derived from plant sources (Yuan et al., 2016). Several synthetic drugs being fre- quently used today have also been developed as the analogues/prototype of the natural phytochemicals, which serve as lead compounds for these synthetic drugs. In India, phytochemicals are not limited to medicinal use only, but also they have been used in cosmetics, health and hygiene, fragrance, and food supplements (Qazi and Raza, 2021).

\section{Conclusion}

Psoriasis is a multidirectional immunogenic issue brought about by hereditary and ecological elements, which includes complex pathogenic collaborations between the inborn and versatile insusceptible framework. Treatment of psoriasis with synthetic medicines is restricted because of its practicability, comfort, and extreme unfavorable adverse effects like hepatotoxicity and renal damage. Plants and their parts have been 
shown to assume an essential function in the revelation of new specialists for the treatment of psoriasis. Numerous plants and various classes of phytochemicals basically flavonoids with various method of activities have been recognized for their intriguing antioxidating, mitigating, wound recuperating, antinfective, antiproliferative impacts for psoriasis. The most encouraging outcomes were gotten from curcumin, indirubin, berberine and boswellic acids from the plants Curcuma longa, Indigo naturalis, Berberis aristata and Boswellia serrata individually. Understanding the mechanismsof activities of postulations different impacts with lesser-known unfriendly impacts and reactions will make these plant products and unadulterated mixtures preferably appropriate for the treatment of psoriasis.

\section{Conflict of interest}

The authors declare that they have no conflict of interest.

\section{REFERENCES}

1. Aggarwal, B. B. \& Harikumar, K. B. (2009). Potential therapeutic effects of curcumin, the anti-inflammatory agent, against neurodegenerative, cardiovascular, pulmonary, metabolic, autoimmune and neoplastic diseases. The International Journal of Biochemistry \& Cell Biology, 41(1), 40-59.

2. Alalaiwe, A., Hung, C. F., Leu, Y. L., Tahara, K., Chen, H. H., Hu, K. Y. \& Fang, J. Y. (2018). The active compounds derived from Psoralea corylifolia for photochemotherapy against psoriasis-like lesions: The relationship between structure and percutaneous absorption. European Journal of Pharmaceutical Sciences, 124, 114-126.

3. Alashqar, M. B. (2019). Caffeine in the treatment of atopic dermatitis and psoriasis: A review. SKIN The Journal of Cutaneous Medicine, 3(2), 59-71.

4. An, J., Li, Z., Dong, Y., Ren, J. \& Huo, J. (2016). Amentoflavone protects against psoriasis-like skin lesion through suppression of NF-kB-mediated inflammation and keratinocyte proliferation. Molecular and Cellular Biochemistry, 413(1-2), 87-95.

5. Anandjiwala, S., Bagul, M. S., Srinivasa, H., Kalola, J. \& Rajani, M. (2007). Antioxidant activity of stem bark of Thespesia populnea Soland ex Corr. Journal of Natural Remedies, 7(1), 135-141.

6. Armstrong, A. W. \& Read, C. (2020). Pathophysiology, clinical presentation, and treatment of psoriasis: a review. Jama, 323(19), 1945-1960.

7. Baker, C. S., Foley, P. A. \& Braue, A. (2013). Psoriasis uncovered-measuring burden of disease impact in a survey of Australians with psoriasis. Australasian Journal of Dermatology, 54, 1-6.

8. Barcelos, R. P., Souza, M. A., Amaral, G. P., Stefanello, S. T., Bresciani, G., Fighera, M. R., Soares, F. A. \& Barbosa, N. V. (2014). Caffeine supplementation modulates oxidative stress markers in the liver of trained rats. Life Sciences, 96(1-2), 40-45.

9. Barrea, L., Muscogiuri, G., Di, S. C., Annunziata, G., Megna, M., Falco, A., Balato, A., Colao, A. \& Savastano,
S. (2018). Coffee consumption, metabolic syndrome and clinical severity of psoriasis: good or bad stuff?. Archives of Toxicology, 92(5), 1831-1845.

10. Berman, B., Ellis, C. \& Elmets, C. (2016). Polypodium leucotomos-an overview of basic investigative findings. Journal of Drugs in Dermatology: JDD, 15(2), 224228.

11. Blažević, T., Heiss, E. H., Atanasov, A. G., Breuss, J. M., Dirsch, V. M. \& Uhrin, P. (2015). Indirubin and indirubin derivatives for counteracting proliferative diseases. Evidence-Based Complementary and Alternative Medicine, 2015, 1-12.

12. Bonesi, M., Loizzo, M. R., Menichini, F. \& Tundis, R. (2018). Flavonoids in treating psoriasis. In Immunity and Inflammation in Health and Disease (pp. 281-294). Academic Press.

13. Bonesi, M., Rosa Loizzo, M., Provenzano, E., Menichini, F. \& Tundis, R. (2016). Anti-psoriasis agents from natural plant sources. Current Medicinal Chemistry, 23(12), 12501267.

14. Buhimschi, A. D., Gooden, D. M., Jing, H., Fels, D. R., Hansen, K. S., Beyer, Jr, W. F., Dewhirst, M. W., Walder, H. \& Gasparro, F. P. (2020). Psoralen Derivatives with Enhanced Potency. Photochemistry and Photobiology, 96 (5), 1014-1031.

15. Chamcheu, J. C., Pal, H. C., Siddiqui, I. A., Adhami, V. M., Ayehunie, S., Boylan, B. T., Noubissi, F. K., Khan, N., Syed, D. N., Elmets, C. A. \& Wood, G. S. (2015). Prodifferentiation, anti-inflammatory and antiproliferative effects of delphinidin, a dietary anthocyanidin, in a fullthickness three-dimensional reconstituted human skin model of psoriasis. Skin Pharmacology and Physiology, 28(4), 177-188.

16. Charlton, O., Phan, K., Smith, S. D. \& Parratt, J. (2019). Psoriasis in family members of patients with multiple sclerosis. Multiple Sclerosis and Related Disorders, 36, 101421.

17. Chen, X., Wu, Y., Jiang, Y., Zhou, Y., Wang, Y., Yao, Y., Lee, S.T., Wu, W.T. \& Yang, J. (2012). Isoliquiritigenin inhibits the growth of multiple myeloma via blocking IL-6 signaling. Journal of Molecular Medicine, 90(11), 13111319.

18. Chen, Z., Zhang, R., Shi, W., Li, L., Liu, H., Liu, Z. \& Wu, L. (2019). The Multifunctional Benefits of Naturally Occurring Delphinidin and Its Glycosides. Journal of Agricultural and Food Chemistry, 67(41), 11288-11306.

19. Chiang, H. M., Lin, Y. T., Hsiao, P. L., Su, Y. H., Tsao, H. T. \& Wen, K. C. (2012). Determination of marked components-aloin and aloe-emodin-in Aloe vera before and after hydrolysis. Journal of Food and Drug Analysis, 20(3), 646652.

20. Choudhary, S., Pandey, A., Khan, M. K., Khan, S. Rustagi, S. \& Thomas, G. (2016). Psoriasis: Role of dietary management in diminution of its symptoms. Biosci Biotech Res Comm, 9, 391-398.

21. Cui, W. Q., Wang, S. T., Pan, D., Chang, B. \& Sang, L. X. (2020). Caffeine and its main targets of colorectal cancer. World Journal of Gastrointestinal Oncology, 12(2), 149-172.Dabholkar, N., Rapalli, V. K., \& Singhvi, G. (2021). Potential herbal constituents for psoriasis treatment as protective and effective therapy. Phytotherapy Research, 35(5), 2429-2444. 
22. Dai, X. Y., Nie, W., Wang, Y. C., Shen, Y., Li, Y. \& Gan, S. J. (2012). Electrospun emodin polyvinylpyrrolidone blended nanofibrous membrane: A novel medicated biomaterial for drug delivery and accelerated wound healing. Journal of Materials Science: Materials in Medicine, 23(11), 27092716.

23. Deitersen, J., El-Kashef, D. H., Proksch, P. \& Stork, B. (2019). Anthraquinones and autophagy-Three rings to rule them all?. Bioorganic \& Medicinal Chemistry, 27(20), 115042

24. Deveci, E., Kocacenk, T., Şahan, E., Yılmaz, O., Öztürk, A. \& Kırpınar, İ. (2019). Oxidative stress and inflammatory response in patients with psoriasis; is there any relationship with psychiatric comorbidity and cognitive functions?. Psychiatry and Clinical Psychopharmacology, 29 (4), 682-695.

25. Di, T. T., Ruan, Z. T., Zhao, J. X., Wang, Y., Liu, X., Wang, Y. \& Li, P. (2016). Astilbin inhibits Th17 cell differentiation and ameliorates imiquimod-induced psoriasislike skin lesions in BALB/c mice via Jak3/Stat3 signaling pathway. International Immunopharmacology, 32, 32-38.

26. Dorjay, K., Arif, T. \& Adil, M. (2018). Silymarin: An interesting modality in dermatological therapeutics. Indian Journal of Dermatology, Venereology and Leprology, 84 (2), 238-243.

27. Ehteshamfar, S. M., Akhbari, M., Afshari, J. T., Seyedi, M., Nikfar, B., Shapouri-Moghaddam, A., Ghanbarzadeh, E., Momtazi-Borojeni, A. A.\& Momtazi-Borojeni, A. A. (2020). Anti-inflammatory and immune-modulatory impacts of berberine on activation of autoreactive $T$ cells in autoimmune inflammation. Journal of Cellular and Molecular Medicine, 24(23), 13573-13588.

28. El-Ahmady, S., Ibrahim, N., Farag, N. \& Gabr, S. (2021). Apiaceae Plants Growing in the East: Centuries of Healing Traditions and Culture. In Ethnopharmacology of Wild Plants (pp. 246-300). CRC Press.

29. Emerson, D. M., Davis, J. M., Chen, S. C., TorresMcGehee, T. M., Pfeifer, C. E., Emerson, C. C., Bivona, J. D. \& Stone, J.V., 2020. A 24 hour naproxen dose on gastrointestinal distress and performance during cycling in the heat. Sports Medicine and Health Science, 2(1), pp.19-24.

30. Esteve, M. (2020). Mechanisms underlying biological effects of cruciferous glucosinolate-derived isothiocyanates/ indoles: a focus on metabolic syndrome. Frontiers in Nutrition, 7, 111, 1-22.

31. Farahnik, B., Sharma, D., Alban, J. \& Sivamani, R. K. (2017). Topical botanical agents for the treatment of psoriasis: a systematic review. American Journal of Clinical Dermatology, 18(4), 451-468.García-Lafuente, A., Guillamón, E., Villares, A., Rostagno, M. A. \& Martínez, J. A. (2009). Flavonoids as anti-inflammatory agents: implications in cancer and cardiovascular disease. Inflammation Research, 58(9), 537-552.

32. García-Pérez, M. E., Allaeys, I., Rusu, D., Pouliot, R., Janezic, T. S. \& Poubelle, P. E. (2014). Picea mariana polyphenolic extract inhibits phlogogenic mediators produced by TNF- $\alpha$-activated psoriatic keratinocytes: Impact on NF-KB pathway. Journal of Ethnopharmacology, 151 (1), 265-278.

33. Gonzales, S., Gilaberte, Y. \& Philips, N. (2010). Mechanistic insights in the use of a Polypodium leucotomos extract as an oral and topical photoprotective agent. Photochemical \& Photobiological Sciences, 9(4), 559-563.

34. Grandi, N. \& Tramontano, E. (2018). HERV envelope proteins: physiological role and pathogenic potential in cancer and autoimmunity. Frontiers in Microbiology, 9, 462, 1-26.Halim, S. A., Khan, A., Csuk, R., Al-Rawahi, A. \& Al-Harrasi, A. (2020). Diterpenoids and Triterpenoids from Frankincense Are Excellent Anti-psoriatic Agents: An in silico Approach. Frontiers in Chemistry, 8, 486, 1-19.

35. Hämäläinen, M., Nieminen, R., Vuorela, P., Heinonen, M. \& Moilanen, E. (2007). Anti-inflammatory effects of flavonoids: genistein, kaempferol, quercetin, and daidzein inhibit STAT-1 and NF-KB activations, whereas flavone, isorhamnetin, naringenin, and pelargonidin inhibit only NF$\mathrm{KB}$ activation along with their inhibitory effect on iNOS expression and NO production in activated macrophages. Mediators of Inflammation, 2007, 1-10.

36. Hassan, B. A. (2018). Evaluation of Antipsoriatic Activity of Topical Curcumin by using Mouse Tail Model. University of Thi-Qar Journal of Medicine, 16(2), 172184.

37. Hung, C. H., Wang, C. N., Cheng, H. H., Liao, J. W., Chen, Y. T., Chao, Y. W., Jiang, J. L. \& Lee, C. C. (2018). Baicalin ameliorates imiquimod-induced psoriasis-like inflammation in mice. Planta Medica, 84(15), 1110-1117.

38. Hussain, H., Al-Harrasi, A., Csuk, R., Shamraiz, U., Green, I. R., Ahmed, I., Khan, I. A. \& Ali, Z. (2017). Therapeutic potential of boswellic acids: a patent review (19902015). Expert Opinion on Therapeutic Patents, 27(1), 8190 .

39. Iriventi, P., Gupta, N. V., Osmani, R. A. M. \& Balamuralidhara, V. (2020). Design \& development of nanosponge loaded topical gel of curcumin and caffeine mixture for augmented treatment of psoriasis. DARU Journal of Pharmaceutical Sciences, 28, 489-506.

40. Janeczek, M., Moy, L., Lake, E. P. \& Swan, J. (2018). Review of the efficacy and safety of topical mahonia aquifolium for the treatment of psoriasis and atopic dermatitis. The Journal of Clinical and Aesthetic Dermatology, 11 (12), 42-47.

41. Johnson, C., Goddard, L. \& Jacob, S. E. (2018). Podophyllotoxin in dermatology. Journal of the Dermatology Nurses' Association, 10(1), 53-56.

42. Kang, D., Liu, A. L., Wang, J. H. \& Du, G. H. (2018) Camptothecin. In Natural Small Molecule Drugs from Plants (pp. 491-496). Springer, Singapore.

43. Kaur, A. \& Kumar, S. (2012). Plants and plant products with potential antipsoriatic activity-A review. Pharmaceutical Biology, 50(12), 1573-1591.

44. Kjaer, T. N., Thorsen, K., Jessen, N., Stenderup, K. \& Pedersen, S. B. (2015). Resveratrol ameliorates imiquimod-induced psoriasis-like skin inflammation in mice. Plos One, 10(5), e0126599.

45. Keshmiri-Neghab, H. \& Goliaei, B. (2014). Therapeutic potential of gossypol: an overview. Pharmaceutical Biology, 52(1), 124-128

46. Kuchekar, A. B., Pujari, R. R., Kuchekar, S. B., Dhole, S N. \& Mule, P. M. (2011). Psoriasis: A comprehensive review. International Journal of Pharmacy \& Life Sciences, 2 (6), 857-877.

47. Kumar, G. K., Dhamotharan, R., Kulkarni, N. M., Mahat, M. Y. A., Gunasekaran, J. \& Ashfaque, M. (2011). Embel- 
in reduces cutaneous TNF- $\alpha$ level and ameliorates skin edema in acute and chronic model of skin inflammation in mice. European Journal of Pharmacology, 662(1-3), 6369.

48. Lebwohl, M. G., Bachelez, H., Barker, J., Girolomoni, G., Kavanaugh, A., Langley, R. G., Paul, C.F., Puig, L., Reich, K. \& van de Kerkhof, P. C. (2014). Patient perspectives in the management of psoriasis: results from the population-based Multinational Assessment of Psoriasis and Psoriatic Arthritis Survey. Journal of the American Academy of Dermatology, 70(5), 871-881.

49. Li, Y., Song, K., Zhang, H., Yuan, M., An, N., Wei, Y., Wang, L., Sun, Y., Xing, Y. \& Gao, Y. (2020). Antiinflammatory and immunomodulatory effects of baicalin in cerebrovascular and neurological disorders. Brain Research Bulletin. (164), 314-324.

50. Li, T., Zeng, Q., Chen, X., Wang, G., Zhang, H., Yu, A., Wang, H. \& Hu, Y. (2018). The therapeutic effect of artesunate on rosacea through the inhibition of the JAK/ STAT signaling pathway. Molecular Medicine Reports, 17 (6), 8385-8390.

51. Li, W., Sun, Y. N., Yan, X. T., Yang, S. Y., Kim, S., Lee, Y. M., Koh, Y. S. \& Kim, Y. H. (2014). Flavonoids from Astragalus membranaceus and their inhibitory effects on LPS-stimulated pro-inflammatory cytokine production in bone marrow-derived dendritic cells. Archives of Pharmacal Research, 37(2), 186-192.

52. Liao, V. W. Y., Narlawar, R., Hibbs, D. E. \& Groundwater, P. W. (2015). Phytotherapies as New Drug sources: gossypol and curcumin. Phytotherapies: Efficacy, Safety, and Regulation, 330.

53. Ligresti, A., De Petrocellis, L. \& Di Marzo, V. (2016). From phytocannabinoids to cannabinoid receptors and endocannabinoids: pleiotropic physiological and pathological roles through complex pharmacology. Physiological Reviews, 96, 1593-1659.

54. Lin, J., Liu, X., Bao, Y., Hou, S., An, L. \& Lin, X. (2008). Effects of isocamptothecin, a novel camptothecin analogue, on proliferation, apoptosis and telomerase activity in HaCaT cells. Experimental Dermatology, 17(6), 530536.

55. Lin, Y. K., See, L. C., Huang, Y. H., Chi, C. C. \& Hui, R. $Y$. (2018). Comparison of indirubin concentrations in indigo naturalis ointment for psoriasis treatment: a randomized, double blind, dosage-controlled trial. British Journal of Dermatology, 178(1), 124-131.

56. Lin, Y. K., Wong, W. R. \& Pang, J. S. (2007). Successful treatment of recalcitrant psoriasis with Indigo naturalis ointment. Clinical and Experimental Dermatology, 32(1), 99-100.

57. Liu, Y.Q., Li, W.Q., Morris-Natschke, S.L., Qian, K., Yang, L., Zhu, G.X., Wu, X.B., Chen, A.L., Zhang, S.Y., Nan, X. \& Lee, K.H. (2015). Perspectives on biologically active camptothecin derivatives. Medicinal Research Reviews, 35(4), 753-789.

58. Lu, X., Du, J., Liang, J., Zhu, X., Yang, Y. \& Xu, J. (2013). Transcriptional regulatory network for psoriasis. The Journal of Dermatology, 40(1), 48-53.

59. Lv, J., Zhou, D., Wang, Y., Sun, W., Zhang, C., Xu, J., Yang, H., Zhou, T. \& Li, P. (2020). Effects of luteolin on treatment of psoriasis by repressing HSP90. International Immunopharmacology, 79, 106070.
60. Maheshwari, R. K., Singh, A. K., Gaddipati, J. \& Srimal, R. C. (2006). Multiple biological activities of curcumin: a short review. Life Sciences, 78(18), 2081-2087.

61. Maan, A. A., Nazir, A., Khan, M. K. I., Ahmad, T., Zia, R., Murid, M. \& Abrar, M. (2018). The therapeutic properties and applications of Aloe vera: A review. Journal of Herbal Medicine, 12, 1-10.

62. Mansouri, P., Mirafzal, S., Najafizadeh, P., SafaeiNaraghi, Z., Salehi-Surmaghi, M. H. \& Hashemian, F. (2017). The impact of topical Saint John's Wort (Hypericum perforatum) treatment on tissue tumor necrosis factor-alpha levels in plaque-type psoriasis: A pilot study. Journal of Postgraduate Medicine, 63(4), 215.

63. Mundada, A. S., Mahajan, M. S., Gangurde, H. H., Borkar, V. S., Gulecha, V. S. \& Khandare, R. A. (2009). Formulation and evaluation of polyherbal antipsoriatic cream. Pharmacology Online, 2, 1185-91.

64. Naveed, M., Hejazi, V., Abbas, M., Kamboh, A. A., Khan, G. J., Shumzaid, M., Ahmad, F., Babazadeh, D., FangFang, X., Modarresi-Ghazani, F. \& XiaoHui, Z. (2018). Chlorogenic acid (CGA): A pharmacological review and call for further research. Biomedicine \& Pharmacotherapy, 97, 67-74.

65. Nestor, M., Bucay, V., Callender, V., Cohen, J. L., Sadick, N. \& Waldorf, H. (2014). Polypodium leucotomos as an adjunct treatment of pigmentary disorders. The Journal of Clinical and Aesthetic Dermatology, 7(3), 13.

66. Nisar, B., Sultan, A., \& Rubab, S. L. (2018). Comparison of medicinally important natural products versus synthetic drugs-a short commentary. Nat. Prod. Chem. Res, 6(2), 308.

67. Nussbaum, L., Chen, Y. L. \& Ogg, G. S. (2021). Role of regulatory $T$ cells in psoriasis pathogenesis and treatment. British Journal of Dermatology, 184(1), 14-24.

68. Oglah, M. K., Bashir, M. K. \& Mustafa, Y. F. (2021). Hypericin and its analogues: a review of their biological activities. Turkish Journal of Field Crops, 26(2), 259-269.

69. Ohara, K., Uchida, A., Nagasaka, R., Ushio, H. \& Ohshima, T. (2009). The effects of hydroxycinnamic acid derivatives on adiponectin secretion. Phytomedicine, $16(2$ -3), 130-137.

70. Oliveira, A.L.D.B., Monteiro, V.V.S., Navegantes-Lima, K.C., Reis, J.F., Gomes, R.D.S., Rodrigues, D.V.S., Gaspar, S.L.D.F. \& Monteiro, M.C. (2017). Resveratrol role in autoimmune disease-a mini-review. Nutrients, 9(12), 1306.

71. Othman, S. N. N., Lum, P. T., Sekar, M., Mazlan, N. A., Yusri, P. Z. S., Ghazali, N. F., Idi, H.M., Azman, S., Ismail, M. \& Noor, A. A. M. (2020). Molecules of interestembelin-a review. Research Journal of Pharmacy and Technology, 13(7), 3485-3493.

72. Papp, K. A., Blauvelt, A., Bukhalo, M., Gooderham, M., Krueger, J. G., Lacour, J. P., Menter, A., Philipp, S., Sofen, H., Tyring, S. \& Padula, S. J. (2017). Risankizumab versus ustekinumab for moderate-to-severe plaque psoriasis. New England Journal of Medicine, 376 (16), 1551-1560.

73. Park, J. E., Cuong, T. D., Hung, T. M., Lee, I., Na, M., Kim, J. C., Ryoo, S., Lee, J. H., Choi, J. S., Woo, M. H. \& Min, B. S. (2011). Alkaloids from Chelidonium majus and their inhibitory effects on LPS-induced NO production in RAW264. 7 cells. Bioorganic \& Medicinal Chemistry Let- 
ters, 21(23), 6960-6963.

74. Parsaeimehr, A., Martinez-Chapa, S. O. \& ParraSaldívar, R. (2017). Medicinal plants versus skin disorders: a survey from ancient to modern herbalism. In The microbiology of skin, soft tissue, bone and joint infections (pp. 205-221). Academic Press.

75. Passos, A. N., de A Rêgo, V. R., Duarte, G. V., Santos e Miranda, R. C., de O Rocha, B. \& de FSP de Oliveira, M. (2019). Facial involvement and the severity of psoriasis. International Journal of Dermatology, 58(11), 13001304.

76. Pellati, F., Borgonetti, V., Brighenti, V., Biagi, M., Benvenuti, S. \& Corsi, L. (2018). Cannabis sativa L. and nonpsychoactive cannabinoids: their chemistry and role against oxidative stress, inflammation, and cancer. BioMed Research International, 2018.

77. Peng, F., Du, Q., Peng, C., Wang, N., Tang, H., Xie, X., Shen, J. \& Chen, J. (2015). A review: the pharmacology of isoliquiritigenin. Phytotherapy Research, 29(7), 969977.

78. Penzer, R. \& Ersser, S. (2010). Principles of skin care: a guide for nurses and health care practitioners. John Wiley \& Sons.

79. Petkova, V. B., Dimitrov, M. V., Nikolova, I. N., Voycheva, C. C., Valchanova, V. G. \& Andreevska, K. G. (2014). Psoriasis influence on the patients' quality of life. World $\mathrm{J}$. Pharm. Pharm. Sci, 8, 1942-8.

80. Pillai, M., Vitekari, H. \& Mane, R. (2012). Evaluation of anti-psoriatic activity of Cyperus rotundus and Phyllanthus emblica. International Journal of Biotechnology, 5 (2), 028-034.

81. Pisoschi, A. M. \& Pop, A. (2015). The role of antioxidants in the chemistry of oxidative stress: A review. European Journal of Medicinal Chemistry, 97, 55-74.

82. Prakash, O. M., Kumar, A. \& Kumar, P. (2013). Anticancer potential of plants and natural products. $A m \mathrm{~J}$ Pharmacol Sci, 1(6), 104-115.

83. Qazi, S., \& Raza, K. (2021). Phytochemicals from Ayurvedic plants as potential medicaments for ovarian cancer: an in silico analysis. Journal of Molecular Modeling, 27 (4), 1-14.

84. Rai, M., Ingle, A., Pandit, R., Paralikar, P. and Rehman, F., 2018. Curcuma longa L.: From Ethnomedicinal to Novel Biomedical Applications Mahendra Rai, Avinash Ingle, Raksha Pandit, Priti Paralikar, Farkhanda Rehman, Netravati Anasane, Pramod Ingle andSuneesh Buxy. In Ethnobotany (pp. 142-161). CRC Press.

85. Ramanunny, A. K., Wadhwa, S., Singh, S. K., Sharma, D. S., Khursheed, R. \& Awasthi, A. (2020). Treatment strategies against psoriasis: principle, perspectives and practices. Current Drug Delivery, 17(1), 52-73.

86. Raphael, I., Nalawade, S., Eagar, T. N. \& Forsthuber, T. G. (2015). T cell subsets and their signature cytokines in autoimmune and inflammatory diseases. Cytokine, 74(1), 5-17.

87. Rengasamy, K. R., Khan, H., Gowrishankar, S., Lagoa, R. J., Mahomoodally, F. M., Khan, Z., Suroowan, S., Tewari, D., Zengin, G., Hassan, S. T. \& Pandian, S. K. (2019). The role of flavonoids in autoimmune diseases: therapeutic updates. Pharmacology \& Therapeutics, 194, 107-131.

88. Richard, E. G. (2020). The science and (lost) art of Pso- ralen plus UVA phototherapy. Dermatologic Clinics, 38 (1), 11-23.

89. Ríos, J. L., Schinella, G. R. \& Andújar, I. (2019). Antipsoriatic Medicinal Plants: From Traditional Use to Clinic. In Ethnobotany (pp. 158-186). CRC Press.

90. Robinson, K. P. \& Chan, J. J. (2018). Colchicine in dermatology: A review. Australasian Journal of Dermatology, 59(4), 278-285.

91. Rotundo, L., \& Pyrsopoulos, N. (2020). Liver injury induced by paracetamol and challenges associated with intentional and unintentional use. World Journal of Hepatology, 12(4), 125-136.

92. Rout, S. K., Tripathy, B. C. \& Kar, B. R. (2017). Natural Green Alternatives to Psoriasis Treatment-A Review. Global Journal of Pharmacy \& Pharmaceutical Sciences, 4(1), 001-007.

93. Sabir, S., Arsshad, M., Asif, S. \& Chaudhari, S. K. (2014). An insight into medicinal and therapeutic potential of SiIybum marianum (L.) Gaertn. Int J Biosci, 4(11), 104-15.

94. Salehi, B., Lopez-Jornet, P., Pons-Fuster López, E., Calina, D., Sharifi-Rad, M., Ramírez-Alarcón, K., Forman, K., Fernández, M., Martorell, M., Setzer, W. N. \& SharifiRad, J. (2019). Plant-derived bioactives in oral mucosal lesions: a key emphasis to curcumin, lycopene, chamomile, aloe vera, green tea and coffee properties. Biomolecules, 9(3), 106.

95. Sarker, S. D., Nahar, L., Miron, A. \& Guo, M. (2020). Anticancer natural products. In Annual Reports in Medicinal Chemistry (Vol. 55, pp. 45-75). Academic Press.

96. Sharma, R., Sahu, P., Jain, A., Kumar, V., Khokhar, D., Geda, A. K. \& Gupta, B. (2019). Nigella sativa. In Nutraceuticals in Veterinary Medicine (pp. 91-101). Springer, Cham.

97. Shenefelt, P. D. (2010). Psychological interventions in the management of common skin conditions. Psychology Research and Behavior Management, 3, 51.

98. Singh, K. K. \& Tripathy, S. (2014). Natural treatment alternative for psoriasis: a review on herbal resources. Journal of Applied Pharmaceutical Science, 4 (11), 114-121

99. Simpson, B. S., Luo, X., Costabile, M., Caughey, G. E., Wang, J., Claudie, D. J., McKinnon, R. A. \& Semple, S. J. (2014). Polyandric acid A, a clerodane diterpenoid from the Australian medicinal plant Dodonaea polyandra, attenuates pro-inflammatory cytokine secretion in vitro and in vivo. Journal of Natural Products, 77(1), 85-91.

100.Singhvi, G., Hejmady, S., Rapalli, V. K., Dubey, S. K. \& Dubey, S. (2020). Nanocarriers for topical delivery in psoriasis. In Delivery of Drugs (pp. 75-96). Elsevier.

101.Schleicher, S. M. (2016). Psoriasis: pathogenesis, assessment, and therapeutic update. Clinics in Podiatric Medicine and Surgery, 33(3), 355-366.

102.Smith, D. (2017). Fumaric acid esters for psoriasis: a systematic review. Irish Journal of Medical Science (1971 -), 186(1), 161-177.

103.Sun, S., Zhang, X., Xu, M., Zhang, F., Tian, F., Cui, J., Xia, Y., Liang, C. \& Zou, Y. (2019). Berberine downregulates CDC6 and inhibits proliferation via targeting JAKSTAT3 signaling in keratinocytes. Cell Death \& Disease, 10(4), 1-16.

104.Sung, Y. Y., Kim, Y. S. \& Kim, H. K. (2012a). Illicium verum extract inhibits TNF- $\alpha$-and IFN- $\gamma$-induced expres- 
sion of chemokines and cytokines in human keratinocytes. Journal of Ethnopharmacology, 144(1), 182-189.

105.Terra, V. A., Souza-Neto, F. P., Frade, M. A. C., Ramalho, L. N. Z., Andrade, T. A. M., Pasta, A. A. C., Conchon, A. C., Guedes, F. A., Luiz, R. C., Cecchini, R. \& Cecchini, A. L. (2015). Genistein prevents ultraviolet B radiationinduced nitrosative skin injury and promotes cell proliferation. Journal of Photochemistry and Photobiology B: Biology, 144, 20-27.

106.Vani, P. B. \& Kumar, P. R. (2020). A Comparative Review on Conventional and Traditional medicine in the Treatment of Psoriasis. Research Journal of Pharmacy and Technology, 13(11), 5642-5646.

107.Vibhooti, P., Ashok, K., Shilpa, S. \& Himani, N. (2016). Fight psoriasis naturally through ayurveda. Pharmaceutical Research, 6(07), 6280-6290.

108.Visconti, M. J., Haidari, W., \& Feldman, S. R. (2020). Therapeutic use of caffeine in dermatology: A literature review. Journal of Dermatology and Dermatologic Surgery, 24(1), 18.

109.Wang, X., Dong, K., Ma, Y., Jin, Q., Yin, S. \& Wang, S. (2020). Hepatoprotective effects of chamazulene against alcohol-induced liver damage by alleviation of oxidative stress in rat models. Open Life Sciences, 15(1), 251-258.

110.Wang, J., Wang, L., Lou, G. H., Zeng, H. R., Hu, J., Huang, Q. W., Peng, W. \& Yang, X. B. (2019). Coptidis Rhizoma: a comprehensive review of its traditional uses, botany, phytochemistry, pharmacology and toxicology. Pharmaceutical Biology, 57(1), 193-225.

111.Wang, J., Zhang, H., Liu, T., Wu, M., Cao, Y., Wu, L., \& $\mathrm{He}, \mathrm{S}$. (2019). Baicalin inhibits the activity of keratinocytes in psoriasis by activating Notch signaling pathway. Xi bao yu fen zi mian yi xue za zhi= Chinese Journal of Cellular and Molecular Immunology, 35(5), 441-446.

112.Wetterauer, B., Wildi, E. \& Wink, M. (2018). Production of the Anticancer Compound Camptothecin in Root and Hairy Root Cultures of Ophiorrhiza mungos L. In Biotechnological Approaches for Medicinal and Aromatic Plants (pp. 303-341). Springer, Singapore.

113.Wilkinson, J. D. \& Williamson, E. M. (2007). Cannabinoids inhibit human keratinocyte proliferation through a non-CB1/CB2 mechanism and have a potential therapeutic value in the treatment of psoriasis. Journal of Dermatological Science, 45(2), 87-92.

114.Wölfle, U., Seelinger, G. \& Schempp, C. M. (2014). Topical application of St. John's wort (Hypericum perforatum). Planta Medica, 80(02/03), 109-120.

115.World Health Organization. (2015). Guidelines for the treatment of malaria. World Health Organization.

116. Wu, X., Deng, X., Wang, J. \& Li, Q. (2020). Baicalin Inhibits Cell Proliferation and Inflammatory Cytokines Induced by Tumor Necrosis Factor $\alpha$ (TNF- $\alpha$ ) in Human Immortalized Keratinocytes (HaCaT) Human Keratinocytes by Inhibiting the STAT3/Nuclear Factor kappa B (NF -KB) Signaling Pathway. Medical science monitor: International Medical Journal of Experimental and Clinical Research, 26, e919392-1.Wu, Y., Chen, X., Ge, X., Xia, H., Wang, Y., Su, S., Li, W., Yang, T., Wei, M., Zhang, H. \& Yang, J. (2016). Isoliquiritigenin prevents the progression of psoriasis-like symptoms by inhibiting NF-KB and proinflammatory cytokines. Journal of Molecular Medicine, 94 (2), 195-206.

117.Xiao, H. B., Sun, Z. L., Zhang, H. B. \& Zhang, D. S. (2012). Berberine inhibits dyslipidemia in C57BL/6 mice with lipopolysaccharide induced inflammation. Pharmacological Reports, 64(4), 889-895.

118.Xie, C., Kang, J., Li, Z., Schauss, A. G., Badger, T. M., Nagarajan, S., Wu, T. \& Wu, X. (2012). The açaí flavonoid velutin is a potent anti-inflammatory agent: blockade of LPS-mediated TNF- $\alpha$ and IL-6 production through inhibiting NF-KB activation and MAPK pathway. The Journal of Nutritional Biochemistry, 23(9), 1184-1191.

119.Xiong, H., Xu, Y., Tan, G., Han, Y., Tang, Z., Xu, W., Zeng, F. \& Guo, Q. (2015). Glycyrrhizin ameliorates imiquimod-induced psoriasis-like skin lesions in BALB/c mice and inhibits TNF-a-induced ICAM-1 expression via NF-kB/MAPK in HaCaT cells. Cellular Physiology and Biochemistry, 35(4), 1335-1346.

120.Yehuda, H., Khatib, S., Sussan, I., Musa, R., Vaya, J. \& Tamir, S. (2009). Potential skin anti-inflammatory effects of $4 \square$ methylthiobutylisothiocyanate (MTBI) isolated from rocket (Eruca sativa) seeds. Biofactors, 35(3), 295-305.

121.Yehuda, H., Soroka, Y., Zlotkin-Frušić, M., Gilhar, A., Milner, Y. \& Tamir, S. (2012). Isothiocyanates inhibit psoriasis-related proinflammatory factors in human skin. Inflammation Research, 61(7), 735-742.

122.Yu, N., Li, Y., Ding, Y. \& Shi, Y. (2020). Combination therapy with acitretin and glycyrrhizin in generalized pustular psoriasis with liver test abnormalities: A case series. Dermatologic Therapy, 33(3), e13318.

123.Yu, S., Yan, H., Zhang, L., Shan, M., Chen, P., Ding, A. \& Li, S. F. Y. (2017). A review on the phytochemistry, pharmacology, and pharmacokinetics of amentoflavone, a naturally-occurring biflavonoid. Molecules, 22(2), 299.

124. Yuan, H., Ma, Q., Ye, L., \& Piao, G. (2016). The traditional medicine and modern medicine from natural products. Molecules, 21(5), 559.

125. Yuan, J., Ding, W., Wu, N., Jiang, S. \& Li, W. (2019). Protective effect of genistein on condylar cartilage through downregulating NF-KB expression in experimentally created osteoarthritis rats. Bio Med Research International, 2019.

126.Zhou, W., Hu, M., Zang, X., Liu, Q., Du, J., Hu, J., Zhang, L., Du, Z. \& Xiang, Z. (2020). Luteolin attenuates imiquimod-induced psoriasis-like skin lesions in BALB/C mice via suppression of inflammation response. Biomedicine \& Pharmacotherapy, 131, 110696.

127.Zhu, X., Liu, J., Chen, S., Xue, J., Huang, S., Wang, Y. \& Chen, O. (2019). Isoliquiritigenin attenuates lipopolysaccharide-induced cognitive impairment through antioxidant and anti-inflammatory activity. BMC Neuroscience, 20(1), 113.

128.Zumbrun, E. E., Sido, J. M., Nagarkatti, P. S. \& Nagarkatti, M. (2015). Epigenetic regulation of immunological alterations following prenatal exposure to marijuana cannabinoids and its long term consequences in offspring. Journal of Neuroimmune Pharmacology, 10(2), 245-254. 